International Journal of Life Sciences
Available online at www.sciencescholar.us
Vol. 4 No. 1, April 2020, pages: 66-77
e-ISSN: 2550-6986, p-ISSN: 2550-6994
https://doi.org/10.29332/ijls.v4n1.379

\title{
The effect of concentrate replacement level with gamal leaf (gliricidia sepium) in ransum on rument metabolite products and blood goat profile
}

\author{
Sigit Perdana a, I Gusti Lanang Oka Cakra ${ }^{b}$, I Gede Mahardika ${ }^{c}$
}

Manuscript submitted: 27 November 2019 Manuscript revised: 09 December 2019, Accepted for publication: 31 January 2020

\section{Corresponding Author ${ }^{b}$}

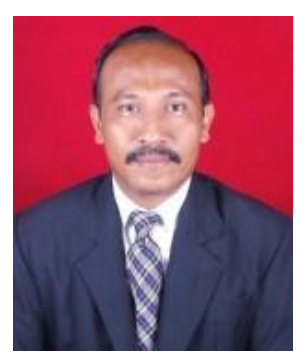

\section{Keywords}

blood profile;

concentrate;

gamal (giricidia sepium);

performance of rumen

metabolites;

treatments;

\section{Abstract}

This study aims to determine the effect of replacing concentrates with Gamal leaves (Gliricidia sepium) in the ration on the product and the performance of rumen metabolites and the blood profile of PE goats. The experimental design used was the Latin square design, $4 \times 4$ that is 4 treatments with four 4 replications each experiment unit consisted of 1 animal. One treatment period for 2 weeks. The first week was adapted and the second week the data collection process was carried out. The treatment given is as follows. The treatments are A (45\% concentrate and 55\% field grass); B (Gamal 15\% with $30 \%$ concentrate and 55\% field grass); C (Gamal 30\% with 15\% concentrate and 55\% field grass); D (Gamal $45 \%$ and field grass 55\%). The results of this study indicate that the effect of the rate of replacement of concentrates with Gamal leaves (Gliricidia sepium) in the ration on rumen metabolite products $\mathrm{PE}$ goat was significantly different $(\mathrm{P}<0.05)$ total VFA concentration and VFA Parcial. The concentration of N-NH3, protozoan population the acidity of $\mathrm{pH}$, methane production showed results that were not significantly different. Blood glucose, total protein, and total cholesterol were not significantly different between treatments $(\mathrm{P}>0.05)$ while blood urea and triglycerides were significantly different between treatments. The results showed that replacing the concentrate with 30\% Gamal leaves reduced total and partial VFA concentrations and decreased blood parameters, namely blood urea and triglycerides.

a Udayana University, Denpasar, Indonesia

b Udayana University, Denpasar, Indonesia

c Udayana University, Denpasar, Indonesia 


\section{Contents}

Abstract

1 Introduction

3 Results and Discussions .........................................................................................................................

4 Conclusion

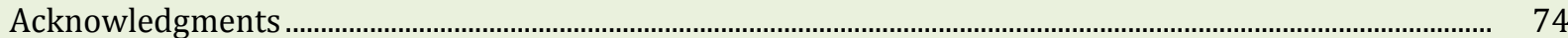

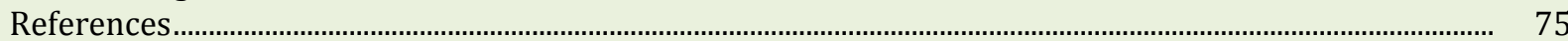

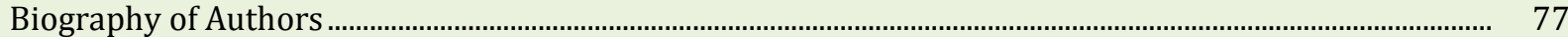

\section{Introduction}

Meeting the needs of the animal protein community and the adequacy of national meat today is a very important aspect to consider. For this reason, the availability of livestock products as a source of animal protein of good quantity and quality is also sustainable. A goat has high adaptability to various environments and cultures of the Indonesian people (Faozi et al., 2013). In the goat breeding business, there are 3 things that must be considered, feed, breed and maintenance management. Good food contains carbohydrates, protein, vitamin fats, minerals and water to grow and reproduce production (Sarwono, 2005). Field grass and foliage have low nutritional content, consequently not fulfilling their basic living needs. Crude protein for weaning goat growth is around $13-14 \%$ (Murtidjo, 1993). Concentrates contain protein and carbohydrates. Murtidjo (1993), Increasing livestock productivity requires the availability of concentrates that contain high nutrients and are easily digested and can be synthesized in large amounts of body tissue. However, if we look at it from its economic aspect, concentrating feed requires a high cost, therefore there needs to be an effort to replace feed with nutrients that are almost the same as the concentrate and easily digested in the rumen, one type of feed is Gamal leaves (Gliricidia sepium). Gamal leaf (Gliricidia sepium) is a food that is easily degraded in the rumen degradable protein (RDP) and can be used as a basal feed for goats or mixed feed through the withering process. According to Hartadi et al. (1990), Gamal nutrients (Gliricidia sepiun) namely 13.3\% crude fiber, $4.0 \%$ BETN ash $8.4 \%$ ash and $25.7 \%$ crude protein. In addition to supporting production, good food must also be able to maintain physiological responses and blood profiles in normal circumstances. Some factors to assess the adequacy of nutrients in PE goats are by looking at rumen metabolite products and blood profile. Based on the description above, it is necessary to conduct research to determine the effect of replacing concentrates with Gamal leaves (Gliricidia sepium) on rumen metabolite products and PE goat blood profile.

\section{Materials and Methods}

\section{Research design}

This research uses a Latin square design, consisting of 4 head of cattle where each animal gets all the same treatments in turn. Where one treatment consists of 2 weeks. The first week was adapted and the second week the data collection process was carried out. The treatment given is as follows.

$A=45 \%$ concentrate and $55 \%$ grass

$\mathrm{B}=$ Gamal $15 \%$ with $30 \%$ concentrate and $55 \%$ field grass

$\mathrm{C}=$ Gamal $30 \%$ with $15 \%$ concentrate and $55 \%$ pitch grass

$\mathrm{D}=$ Gamal $45 \%$ with field grass $55 \%$

The feed given in this study consisted of field grass and Gamal leaves and concentrate as additional feed. Giving field grass as basic feed, concentrate and Gamal leave 3\% BK of livestock body weight. The concentrate is first given at 08.00 West Indonesia Time and then the Gamal leaves are given ad libitum field grass Feed

Perdana, S., Cakra, I. G. L. O., \& Mahardika, I. G. (2020). The effect of concentrate replacement level with gamal leaf (gliricidia sepium) in ransum on rument metabolite products and blood goat profile. International Journal of Life Sciences, 4(1), 66-77. https://doi.org/10.29332/ijls.v4n1.379 
given to livestock is first weighed then tomorrow morning the non-consumed feed is weighed again to find out the amount of consumption. Drinking water is given ad libitum and put into a 5 -liter bucket

\section{Location and time of research}

This research was conducted in Karangasem Regency, Sidemen Village for 12 weeks. The first two weeks are for the preparation of tools and research materials as well as the adaptation of livestock to the feed given and 10 weeks for the research process. Rumen fluid samples were analyzed in the Nutrition and Animal Food laboratory of the Udayana Animal Husbandry Faculty and blood samples at the Mantra Medika laboratory, Denpasar.

\section{Animal research}

The experimental animals in this study were 4 PE goats, ranging in age from 1,5 - 2 years. The determination of the age of livestock is based on the condition of goat incisors with an average weight of $40 \mathrm{~kg} / \mathrm{head}$. The cage to be used is the stage cage with a tin roof, the floorboards, the walls of the boards. The enclosure is made into 4 plots with a size of $1.0 \times 1.70$ meters each placed by a goat. Each plot is equipped with a feed tub made of boards and a bucket for drinking.

\section{Tools and materials}

The research instruments that will be used are hanging scales, digital scales, tarps, plastic buckets, plastic bags, vacuum pumps, scythes and machetes, cameras and stationery. The materials used are the composition of rations $\mathrm{A}, \mathrm{B}, \mathrm{C}$, and $\mathrm{D}$.

\section{Feed and drinking water}

The feed is given during Gamal (Gliricidia sepium) and concentrates as feed replacement and as the main feed field grass. Field grass is obtained from the edge of the road and around the rice fields with a variety of species that grow in these places. The concentrate given is in the form of flour-based on the composition of food substances according to the recommendation of Kearl (1982). Drinking water is supplied from a spring (wellbore). The content of nutrients and ingredients can be seen in the following table:

Table 1

Table composition of concentrated, Gamal (Gliricidia sepium) and grass material

\begin{tabular}{ll}
\hline Concentrated Composition & Concentrated \\
\hline Mpok jagung & 30 \\
Molases & 5 \\
Rice bran & 30 \\
Pollard & 29 \\
CaCO3 (Chalk) & 2 \\
Urea & 1,8 \\
Salt & 2 \\
Pignoq & 0,2 \\
\hline
\end{tabular}

Table 2

Table of concentrates of nutrients, Gamal (Gliricidia sepium) and grass nutrients

\begin{tabular}{llll}
\hline Nutrient content & Concentrate & Gamal(Gliricidia sepium) & Grass \\
\hline Dry Ingredients (\%) & 85,75 & 82,64 & 20,97 \\
Crude protein (\%) & 22,87 & 22,19 & 12,5 \\
Coarse Fat (\%) & 3,29 & 18,93 & 3,89
\end{tabular}




\begin{tabular}{|c|c|c|c|c|c|}
\hline $\begin{array}{l}\text { Coarse Fiber (\%) } \\
\text { TDN (\%) }\end{array}$ & $\begin{array}{l}9,17 \\
74,1\end{array}$ & & 3,32 & \multicolumn{2}{|r|}{$\begin{array}{l}23,71 \\
49,5\end{array}$} \\
\hline \multicolumn{6}{|c|}{ Source: Results of laboratory analysis of nutrition and animal feed of Udayana University, 20} \\
\hline \multicolumn{6}{|c|}{$\begin{array}{c}\text { Table } 3 \\
\text { Composition of treatment rations }\end{array}$} \\
\hline \multirow{2}{*}{ Feed (\%) } & & \multicolumn{4}{|c|}{ Treatment } \\
\hline & & A & $\mathrm{B}$ & $\mathrm{C}$ & $\mathrm{D}$ \\
\hline Concentrate & & 45 & 30 & 15 & 0 \\
\hline Gamal (Gliricid & um) & 0 & 15 & 30 & 45 \\
\hline Grass & & 55 & 55 & 55 & 55 \\
\hline
\end{tabular}

Research variable

Variables in this study include rumen fluid pH, NH3 levels, total VFA levels, protozoan populations, blood profiles including glucose levels, triglyceride levels, total protein, total cholesterol and blood $\mathrm{N}$ urea levels.

\section{Rumen liquid preparation}

The process of taking rumen fluid is carried out 4 hours after morning feeding at the end of the total collection period by using a vacuum pump. As for the method of picking up as follows, firstly all tools such as plastic hose with a length of $250 \mathrm{~cm}$, pipe paralon $40 \mathrm{~cm}$, Erlemeyer scattered, pumps, film bottles, filters, and whistles. Then the device is arranged in such away. The tip of the plastic pipe is inserted into the mouth of the animal until it reaches the reticulorumen with the help of a paralon pipe to prevent animal bites. Suctioning is carried out several times to remove rumen fluid and it is accommodated in Erlenmeyer kettles. After the rumen fluid is obtained around $50-100 \mathrm{ml}$ the desludging is stopped and the plastic pipe is pulled out. The rumen fluid obtained is directly tested for its acidity $(\mathrm{pH})$ using a $\mathrm{pH}$ meter, then filtered. Part of the filtered rumen was analyzed to determine the protozoan population with a part of $\mathrm{H} 2 \mathrm{SO} 4$ drops of 2-3 drops per $50 \mathrm{ml}$. Furthermore, it is taken to the laboratory to analyze the concentration of remnant metabolites, namely total VFA and N-NH3.

\section{Value of rumen fluid $\mathrm{pH}$}

To know the $\mathrm{pH}$ value of rumen fluid in this study using a pH meter. Before being used is standardized by dipping the probe into the buffer until the $\mathrm{pH}$ value $=7$. The feed is given first, after 4 hours the rumen fluid is taken immediately using a vacuum pump through the mouth of the cattle as much as $10 \mathrm{ml}$.

\section{Protozoa calculation}

The calculation of protozoa using MFS (Methylgreen Formalin Saline) dye MFS solution consisted of $100 \mathrm{ml}$ $35 \%$ formaldehyde, $0.6 \mathrm{~g}$ methyl green, $80 \mathrm{~g} \mathrm{NaCl}$ and $900 \mathrm{ml}$ aqua dest. Stages of work are rumen fluid samples taken and then mixed with MFS solution. 1: 4 or 1: 8 ratio. Then 2 drops of the mixture are placed on a counting chamber with a thickness of $0.1 \mathrm{~mm}$ and the smallest box area of $0.0625 \mathrm{~mm} 2$, the number of boxes 16 is mounted with glass cover. Protozoa population calculations using a microscope with 100 times proportions

Protozoa calculations use the formula:

$$
\text { The number of protozoa } / \mathrm{m}=\frac{1}{0,1 \times 0,0625 \times 16} \times 100 \times Z x F p
$$

Information

$\mathrm{Z}=$ Number of protozoa in the counting chamber.

$\mathrm{Fp}=$ dilution factor

Total VFA concentration

Perdana, S., Cakra, I. G. L. O., \& Mahardika, I. G. (2020). The effect of concentrate replacement level with gamal leaf (gliricidia sepium) in ransum on rument metabolite products and blood goat profile. International Journal of Life Sciences, 4(1), 66-77. https://doi.org/10.29332/ijls.v4n1.379 
Determination of total VFA concentrations using the General laboratory procedure (steam distillation). Put into a distilled tube that has been heated with boiling water $5 \mathrm{ml}$ of rumen fluid supernatant with a distillation flask. Close the tube tightly with $1 \mathrm{ml}$ of $15 \% \mathrm{H} 2 \mathrm{SO} 4$ solution immediately added. Then the VFA will be pressed by the steam water pan that passes through the condensed cooling tube and will then be accommodated in an Erlenmeyer tube that has been filled with $0.5 \mathrm{~N} \mathrm{NaOH}$ to a volume of 100-300 ml. Perform the titration process with $0.5 \mathrm{~N} \mathrm{HCL}$ after adding 2-3 drops of the phenoplatin indicator. Titrate blank $5 \mathrm{ml} \mathrm{NaOH}$ first, titration ends if the starting point of the pink discoloration turns clear. Total VFA levels are calculated using the formula:

Information:

Total VFA = (b-s) x NHCL x $100 / \mathrm{mM}$

$\mathrm{s}:$ Sample titration volume

$\mathrm{b}$ : Titration volume blank $(\mathrm{ml})$

$\mathrm{N}$ : The normality of HCL solution

Partial VFA concentrations (acetate, propoinate, butyrate)

VFA concentrations were measured by gas chromatography techniques (AOAC 1990). Rumen fluid samples were analyzed by centrifuging at $40 \mathrm{C}$ for 15 minutes at $10,000 \mathrm{rpm}$ for 15 minutes. The supernatant is taken after centrifuged as much as $\pm 2 \mathrm{ml}$ and put into a small plastic covered. Then $50 \mathrm{mg}$ of C6H3 (OH) SO3 $2 \mathrm{H} 20$ (Sulphosalicylic acid) is added and then the bag is homogeneously centrifuged the mixture again at 40c for 10 minutes at $300 \mathrm{rpm}$. Take the clear liquid as much as $1 \mathrm{ml}$ after filtering by coating, inject the standard VFA solution of acetate (C2), proinate (C3) and butyrate (C4) into gas chromatography.

The partial VFA concentration is calculated by the formula:

\section{Methane production}

$$
V F A \operatorname{Parsial}(m M)=\frac{\text { high sample }}{\text { standard heigh }} x \text { standard concentration }
$$

Estimated methane production can be done based on the formula: (Ryle \& Orskov, 1990), which is as follows: Methane $(\mathrm{mM})=0.5$ Acetate -0.25 Propionate +0.5 Butyrate

\section{$N$-NH3 concentration}

The determination of ammonia is determined by the amount of ammonia-based on the color reaction in rumen fluid that can be read with the eye or with a spectrophotometer. The operation phase is as follows: the equipment used will first be cleaned and arranged according to work procedures. Provide a bottle containing 4-5 drops of concentrated sulfuric acid and then add $15 \mathrm{ml}$ of rumen liquid, then rumen liquid is diluted 100 times using distilled water. Then the rumen fluid to be analyzed is inserted into a test tube that has been filled with a standard solution that has been prepared. Add in succession $0.2 \mathrm{ml}$ of phenol larvae, $0.2 \mathrm{ml}$ of sodium nitriprusidde solution and 0.5 oxidizing solutions (Nuriyasa et al., 2018). Then for 5 minutes after blowing the oxidation solution using a spectrophotometer, the color reaction reading is done.

\section{Blood sample}

Blood samples were taken through the jugular vein 4 hours after the animals were fed at the end of the total collection using a vacuum tube and to separate centrifuge plasma at $500 \mathrm{rpm}$ for 10 minutes. Furthermore, blood plasma is stored at 200C. As long as there is no laboratory analysis (Sandi et al., 2017).

\section{Statistical analysis}

The data obtained were analyzed by analysis of variance if between treatments there were significantly different followed by Duncan multiple distance testing (Steel \& Torrie, 1995). 


\section{Results and Discussions}

The results of this study found that average VFA concentrations ranged from $91.76 \mathrm{mM}-162.44 \mathrm{mM}$ statistically showing significantly different results $(\mathrm{P}<0.05$ ) between treatments (Table 5.1$)$. Treatment A had a high VFA concentration of $162.44 \mathrm{mM}$ when compared to other treatments, while treatment D (45\% Gamal + $55 \%$ grass) had the lowest VFA concentration of $91.76 \mathrm{mM}$, this was due to the high quality of feed which was reflected in the fiber content low coarse or anti-nutrient substances in Gamal leaves.

Treatment A shows that the feed is very easily fermented by rumen bacteria and is able to ferment concentrates and grass components. The provision of $45 \%$ concentrate and $55 \%$ field grass resulted in high total VFA concentrations in treatment A, but the total VFA production of all treatments had fulfilled the maximum requirements for rumen microbial performance. The soluble carbohydrate content contributes to the increase in the concentration of VFA in treatment $A$ which reflects good feed fermentability. Fermentation of carbohydrates from the feed in the rumen is one instrument to determine the total VFA production which is related to livestock productivity (Pamungkas et al., 2008). According to McDonald \& Howard, (2002), a high VFA value refers to feed ingredients having a high enough fermentability. The increase in the amount of VFA is an indication of the fast or slow feed fermentation by rumen microbes, the physical form, and composition of the feed also affect VFA. The high concentration of VFA indicator is an adequate source of energy for livestock (Sakinah, 2005). VFA is the result of rumen fermentation which is very important besides rumen microbes (Kurniawati, 2007). VFA content contained in rumen fluid is a benchmark in seeing the efficiency of the fermentation process in the rumen of food (Suherman et al., 2013). The level of concentration in this study is still in the normal range. According to McDonald et al. (2010), the VFA range is 70-150 mM. According to Asikin (2015), the total normal VFA between 108-117 mM means that it is still good for bacterial performance and VFA production.

There are three partial VFA concentrations analyzed in this study, namely acetic acid, propionic and butyric. The analysis showed that the concentrations between acetate, propionate, and butyrate were significantly different $(\mathrm{P}<0.05)$ between treatments. Goats that received treatment $A$, the average concentration of acetate was $58.84 \mathrm{mM}$ higher than the average concentration of treatment D $44.77 \mathrm{mM}$. The highest propinic acid concentration was obtained in treatment B goats $38.85 \mathrm{mM}$. The D treatment got the lowest concentration of $20.9 \mathrm{mM}$. The highest butyric concentration in goat A treatment was $10.95 \mathrm{mM}$ and the lowest was D $5.07 \mathrm{mM}$. Carbohydrates in feed determine the amount of VFA in rumen fermentation products. The high acetate concentration in treatment $\mathrm{A}$ is classified as having a high fiber content because there is grass and the feed source of energy is easily fermented in the concentrate. Fermented products in the rumen provide a useful source of energy for microbes and hosts that are optimal in treatment A with a higher amount of concentrate than other treatments. Ruminants basically consume more fibrous feed during the fermentation process which is converted to VFA with a ratio of C2 (70): C3 (20): C4 (10) which usually meets $70-80 \%$ of the energy needs for livestock (Fance \& Djikstra, 2005). The production of acetic acid (C2), propionate (C3) and butyrate (C4) are largely dependent on fermentation of carbohydrate feed even though partly comes from feed protein (Sio et al., 2017). Ammonia concentration is determined by the content of feed protein, rumen $\mathrm{pH}$, length of feed in the rumen, degree of degradability (Haryanto, 1994).

$\mathrm{N}-\mathrm{NH} 3$ in treatment A was $5.84 \mathrm{mM}, \mathrm{B}$ was $9.38 \mathrm{mM}, \mathrm{C}$ was $5.10 \mathrm{mM}$ and D was $6.36 \mathrm{mM}$ statistically the results were not significantly different $(\mathrm{P}>0.05)$ between treatments. Fluctuations in N-NH3 concentrations can occur due to the high value of crude protein in the feed as contained in treatment $\mathrm{B}$ where the composition of feed ingredients consists of Gamal, concentrate and field grass consumed. The amount of feed protein consumed, the length of feed is in the rumen and the $\mathrm{pH}$ of the rumen is the degree of degradability, determining the level of ammonia concentration (Haryanto, 1994). N-NH3 concentrations in the normal range between treatments where optimal bacterial development is supported according to McDonald \& Howard, (2002), the ideal range for bacterial growth of 6-12 mM. The results of the degradation process of amino acids

Perdana, S., Cakra, I. G. L. O., \& Mahardika, I. G. (2020). The effect of concentrate replacement level with gamal leaf (gliricidia sepium) in ransum on rument metabolite products and blood goat profile. International Journal of Life Sciences, 4(1), 66-77. https://doi.org/10.29332/ijls.v4n1.379 
and peptides produce N-NH3 which is very important in protein synthesis and protein degradation in the feed (McDonald et al., 2010).

Table 4

Rumen metabolites of PE goats fed with concentrates feed were replaced with Gamal (Gliricidia sepium)

\begin{tabular}{llllll}
\hline \multirow{2}{*}{ Parameters } & \multicolumn{2}{l}{ Treatment } & \multicolumn{2}{l}{ SEM } \\
\cline { 2 - 5 } & A & B & C & D & \\
\hline VFA Total (mM) & $162,44^{\mathrm{a}}$ & $145,46^{\mathrm{ab}}$ & $129,47^{\mathrm{b}}$ & $91,76^{\mathrm{c}}$ & 11,22 \\
Asetat $(\mathrm{mM})$ & $58,84^{\mathrm{a}}$ & $55,34^{\mathrm{a}}$ & $57,49^{\mathrm{ab}}$ & $44,78^{\mathrm{b}}$ & 4,4 \\
Propinat $(\mathrm{mM})$ & $36,90^{\mathrm{a}}$ & $38,85^{\mathrm{a}}$ & $27,70^{\mathrm{b}}$ & $20,90^{\mathrm{b}}$ & 2,63 \\
Butirat $(\mathrm{mM})$ & $10,95^{\mathrm{a}}$ & $6,95^{\mathrm{b}}$ & $7,35^{\mathrm{b}}$ & $5,07^{\mathrm{c}}$ & 0,7 \\
$\mathrm{~N}-\mathrm{NH} 3(\mathrm{mM})$ & $5,84^{\mathrm{a}}$ & $9,38^{\mathrm{a}}$ & $5,10^{\mathrm{a}}$ & $6,36^{\mathrm{a}}$ & 1,09 \\
Protozoa $\left(\mathrm{x} 10^{4}\right)$ sel/ml & $30,79^{\mathrm{a}}$ & $26,81^{\mathrm{ab}}$ & $21,31^{\mathrm{ab}}$ & $19,31^{\mathrm{b}}$ & 3,57 \\
Value Ph & $6,42^{\mathrm{a}}$ & $6,41^{\mathrm{a}}$ & $6,24^{\mathrm{a}}$ & $6,20^{\mathrm{a}}$ & 0,08 \\
MetanProduction $(\mathrm{mM})$ & $26,68^{\mathrm{a}}$ & $21,48^{\mathrm{a}}$ & $25,55^{\mathrm{a}}$ & $19,66^{\mathrm{a}}$ & 1,91 \\
\hline
\end{tabular}

Note: (A) $45 \%$ concentrate $+55 \%$ field grass; (B) Gamal 15\% $+30 \%$ concentrate $+55 \%$ field grass; (C) Gamal $30 \%+15 \%$ concentrate + field grass. (D) Gamal $45 \%+$ field grass $55 \%$. Lift followed by different letters on the same line shows significantly different differences $(\mathrm{P}>0.05)$.

The highest protozoan population was found in treatment A $30.79 \mathrm{mM}$ and the lowest was in treatment D $19.31 \mathrm{mM}$. The mean protozoan population values of all treatments showed results that were not significantly different $(\mathrm{P}>0.05)$. Protozoa population is the lowest in cattle that are treated $\mathrm{D}$ with the treatment by giving large amounts of Gamal where Gamal contains anti-nutrient substances, one of which is saponin. According to Ozutsumi et al. (2005), microbial fermentation in the rumen is a very complex interaction because it is influenced by feed nutrients which will affect the rumen protozoan population. The effect of saponins is to reduce the number of protozoan populations. This makes it possible for the toxic nature of saponins to be protozoan populations (Santoso \& Hariadi, 2007). Saponins are toxic to bacteria and protozoa in the rumen. Approximately $9-25 \%$ of methenogens are bersibiosis with protozoa by sticking to the surface (Santoso \& Hariadi, 2007). A decrease in the protozoan population by feeding Gamal and field grass is a positive result where the decrease in the protozoan population will be accompanied by an increase in the bacterial population in the rumen including fiber-degrading bacteria.

The degree of acidity $(\mathrm{pH})$ in goats treated $\mathrm{A}, \mathrm{B}, \mathrm{C}$ and D are $6.42 ; 6.41 ; 6.24$; and 6.20 which statistically showed results that were not significantly different $(\mathrm{P}>0.05)$. In treatment $\mathrm{D}$, goats get a low yield, because most of all treatments given are 45\% Gamal and 55\% field grass. The low pH of the rumen may have something to do with the content of anti-nutrient substances in treatment $\mathrm{D}$ which caused the rumen to become acidic. Low rumen $\mathrm{pH}$ can reduce the protozoa population drastically, low $\mathrm{pH}$ will make the rumen condition acidic (Nuriyasa et al., 2018). (Table 5.1). In this study, the average $\mathrm{pH}$ of rumen fluid was still normal. To maintain rumen metabolic value $(\mathrm{pH})$ between 6.0-7.0 (Sung et al., 2006). According to Cardoso et al. (2003), the optimal $\mathrm{pH}$ value of rumen fluid is 6.4 and suboptimal $\mathrm{pH}$ is 5.5. The highest $\mathrm{pH}$ value is 7.0, low pH 5.1 and suboptimal pH 5.5-5.4.

The average results of this study showed the production of $\mathrm{CH} 4$ in PE goats in treatments $\mathrm{A}, \mathrm{B}, \mathrm{C}$ and D were 26.68, 21.48, 25.55 and 19.66 (Table 5.1). Statistically, the results were not significantly different (P $<0.05$ ). Where treatment $\mathrm{D}$ of $\mathrm{CH} 4$ production is lower where livestock is more efficient in utilizing the food consumed. Treatment D illustrates the high utilization of feed with little energy wasted through the defaunation process. This is caused by feeding with $45 \%$ Gamal and 55\% field grass and the presence of antinutrients (saponins and tannins) in Gamal helps the process of methane gas reduction in livestock. The reduced concentration of methane gas is due to the reduced number of protozoa which are symbiotic sites of methanogenic bacteria. This is in line with the results obtained in this study where methane production was the lowest in treatment $\mathrm{D}$, the number of protozoans was the lowest in treatment $\mathrm{D}$. This may be due to the lack of development of acetogenic bacteria due to the presence of antinutritional substances in the gamal so that the $\mathrm{CO} 2$ and $\mathrm{H} 2$ that is formed leads to the formation of methane. According to Arora (1995), methane gas 
is produced from $\mathrm{CO} 2$ which reacts with $\mathrm{H} 2 . \mathrm{CO} 2$ and $\mathrm{H} 2$ gas are by-products of the digestive process of carbohydrates in the rumen. The process of methanogenesis is carried out by microorganisms in the rumen that utilize $\mathrm{H} 2$ and $\mathrm{CO} 2$ to produce methane gas. In addition, the production of acetate and propionate in treatment D tends to be higher so that it can spur an increase in CH4 (Moss et al., 2000).

In this study the results obtained average goat blood glucose in treatment A $112.97 \mathrm{mg} / \mathrm{dL}, \mathrm{B} 91.07 \mathrm{mg} /$ $\mathrm{dL}, \mathrm{C} 83.47 \mathrm{mg} / \mathrm{dL}$ and D 82, $67 \mathrm{mg} / \mathrm{dL}$. Statistically, the results between treatments were not significantly different $(\mathrm{P}>0.05)$. The high blood glucose in treatment $\mathrm{A}$ was caused by the presence of carbohydrate sources of food in the concentrate where the highest amount of concentrate was given among the other treatments, so cattle were not optimally utilizing the energy sources contained therein. Manalu et al. (1999), High blood glucose concentration because the food consumed has undergone carbohydrate hydrolysis in the presence of carbohydrate-breaking enzymes into glucose. In ruminants to maintain blood glucose, namely through the endogenous process functions for essential tissue in the body (Arora, 1995). The results of this study indicate higher blood glucose levels compared to research Yupardhi et al. (2014), that goat blood glucose levels are at $64.67 \mathrm{mg} / \mathrm{dL}$.

In this study the highest average blood urea in animals that received A treatment (45\% concentrate $+55 \%$ grass) $22,25 \mathrm{mg} / \mathrm{dl}$ and the lowest in animals that received D treatment (45\% Gamal $+55 \%$ field grass) 17, 68 $\mathrm{mg} / \mathrm{dl}$ which statistically shows significantly different results $(\mathrm{P}<0.05)$. The high blood urea in treatment $\mathrm{A}$ is due to the presence of additional intake of protein from urea as a mixture of constituent compounds in the treatment as non-protein nitrogen (NPN).

The occurrence of rumen N-NH3 absorption and the number of amino acids that are oxidized, absorbed affect the blood urea concentration in livestock. Blood urea is also associated with the needs of microorganisms in the rumen and reflects the level of nitrogen balance in the rumen (Rusdi, 2006). No influence of blood urea concentration between treatments because the amount of protein in the ration given to livestock is almost equal to an average of $22 \%$. High blood urea levels indicate that the conversion of rumen $\mathrm{NH} 3$ to amino acids for microbial protein synthesis is not running optimally. Conversely, low blood urea levels indicate that the conversion of $\mathrm{NH} 3$ to amino acids for maximal microbial protein synthesis. High blood urea concentrations make cattle inefficient in utilizing the energy they consume (Roseler et al., 1993). As in the study (Manu, 2007) in goats normal blood urea levels between 13-44 mg/Dl. Inefficient use of energy consumed due to high blood urea levels (Roseler et al., 1993).

To convert the concentration of rumen ammonia into blood ammonia requires a large energy source and then continued in the form of urea in the urine (Purbowati, 2007).

Table 5

Blood profile of PE goats fed with concentrates feed was replaced with Gamal (Gliricidia sepium)

\begin{tabular}{llllll}
\hline \multirow{2}{*}{ Parameters } & \multicolumn{5}{c}{ Treatment } \\
\cline { 2 - 6 } & $\mathrm{A}$ & $\mathrm{B}$ & $\mathrm{C}$ & $\mathrm{D}$ & SEM \\
\hline Blood Glucose & $112,9^{\mathrm{a}}$ & $91,07^{\mathrm{a}}$ & $82,67^{\mathrm{a}}$ & $83,47^{\mathrm{a}}$ & 6,09 \\
Blood urea & $22,25^{\mathrm{a}}$ & $21,02^{\mathrm{ab}}$ & $19,0^{\mathrm{bc}}$ & $17,68^{\mathrm{b}}$ & 0,65 \\
Triglycerides & $16,25^{\mathrm{a}}$ & $12,25^{\mathrm{ab}}$ & $11,0^{\mathrm{b}}$ & $9,5^{\mathrm{b}}$ & 1,23 \\
Total Protein & $7,86^{\mathrm{a}}$ & $8,28^{\mathrm{a}}$ & $7,57^{\mathrm{a}}$ & $8,14^{\mathrm{a}}$ & 0,47 \\
Cholesterol Total & $118,75^{\mathrm{a}}$ & $128,5^{\mathrm{a}}$ & $108,5^{\mathrm{a}}$ & $97^{\mathrm{a}}$ & 5,53 \\
\hline
\end{tabular}

Note: (A) $45 \%$ concentrate $+55 \%$ field grass; (B) Gamal 15\% $+30 \%$ concentrate $+55 \%$ field grass; (C) Gamal $30 \%+15 \%$ concentrate + field grass. (D) Gamal $45 \%+$ field grass $55 \%$. Lift followed by different letters on the same line shows significantly different differences $(\mathrm{P}>0.05)$

In this study, the highest triglyceride was in treatment $A 16.25 \mathrm{mg} / \mathrm{dl}$ and the lowest was at treatment $9.5 \mathrm{mM}$ as in table 5.1. Statistically showed significantly different results $(\mathrm{P}<0.05)$. The high triglycerides in treatment A because of the sufficient nutrients present in the ration as stated by Gagah et al. (2016), the lipid content in the blood of ruminants is influenced by the feed given, if the feed consumed contains good nutrients will

Perdana, S., Cakra, I. G. L. O., \& Mahardika, I. G. (2020). The effect of concentrate replacement level with gamal leaf (gliricidia sepium) in ransum on rument metabolite products and blood goat profile. International Journal of Life Sciences, 4(1), 66-77. https://doi.org/10.29332/ijls.v4n1.379 
produce higher triglyceride values. Triglycerides are one of the body's energy reserves. The body will remodel triglycerides into energy if the energy in the feed does not meet the body's energy needs (Cunningham, 2002). The highest average total blood protein in this study was in the treatment D $8.41 \mathrm{mg} / \mathrm{dL}$. Statistically, the results were not significantly different $(\mathrm{P}>0.05)$ between treatments. The total height of the protein is thought to be due to the administration of $45 \%$ Gamal leaves where the legume as rumen degradable protein (RDP) is easily absorbed directly inside the rumen. Protein absorption in the treatment D diet is better this is presumably because the feed protein is partially broken down in the rumen by rumen microorganisms into amino acids and peptides and some un-fermented protein is absorbed directly into the rumen wall, the excess amino acids brought to the liver and converted to ammonia. Salido et al. (2016), states that protein is absorbed by the animal's body in the form of amino acids and the availability of sufficient protein will increase the activity and growth of microorganisms so that the process of digestion and consumption also increases.

In this study the average total cholesterol in treatment A was $118.75 \mathrm{mg} / \mathrm{dl} ; \mathrm{B} 128.50 \mathrm{mg} / \mathrm{dl}$, C 108.50 $\mathrm{mg} / \mathrm{dl}$, and D $97.00 \mathrm{mg} / \mathrm{dl}$. Statistically showed no significant difference $(\mathrm{P}>0.05)$. The low total cholesterol concentration in the D treatment was affected by the quality of the treatment ration containing antinutrient substances on the gamal leaves (tannins saponins and flavonoids) which inhibited the absorption of cholesterol in the intestine so as to reduce cholesterol concentration.

The tannin content of the gamal leaf can coat the intestine and bind to proteins so that it inhibits the absorption of carbohydrates, proteins, and lipids. According to Oluremi \& Andrew (2007), tannins and saponins result in inhibited absorption of cholesterol in the intestine so as to reduce blood cholesterol levels. Furthermore, Kinsela et al. (1993), stated that plants containing flavonoids function as antioxidants in inhibiting oxidation, especially lipid compounds and lowering blood cholesterol. These results indicate a higher cholesterol content with research Gagah et al. (2016), which is between 58 mg / dL - $81 \mathrm{mg} / \mathrm{dL}$.

\section{Conclusion}

The effect of the rate of replacement of concentrates with Gamal leaves as much as 30\% (Gliricidia sepium) in the ration on the performance of rumen metabolites and blood profile Reducing total and partial VFA concentrations, has no effect on $\mathrm{NH} 3$, protozoa populations, $\mathrm{pH}$ and methane gas and significantly influences and decreases blood parameters in urea and triglycerides. Then it is recommended to replace the concentrate with Gamal leaves (Gliricidia sepium) as much as $30 \%$.

\section{Acknowledgments}

Thank you very much to Prof. Dr. Ir. I Gede Mahardika., MS. Dr. Ir. I Gusti Lanang Oka Cakra., M.Si has allowed to carry out research in place and Sofyan as a friend in research. 


\section{References}

Arora, S. P. (1995). Pencernaan Mikroba Pada Ruminansia. Diterjemahkan Oleh: Retno Murwani.

Asikin, N. (2015). Karakteristik fermentasi rumen pada ternak kambing kacang jantan yang di beri pakan komplit berbasis tongkol jagung mengandung sumber protein yang berbeda. Skripsi. Fakultas Peternakan, Univerrsitas Hasanuddin. Hal, 13.

Cardoso, C., Leventer, R. J., Ward, H. L., Toyo-Oka, K., Chung, J., Gross, A., ... \& Mutchinick, O. M. (2003). Refinement of a 400-kb critical region allows genotypic differentiation between isolated lissencephaly, Miller-Dieker syndrome, and other phenotypes secondary to deletions of $17 \mathrm{p} 13$. 3. The American Journal of Human Genetics, 72(4), 918-930. https://doi.org/10.1086/374320

Cunningham J. G. (2002). Textbook of Veterinary Phisiology. New York (USA): Saunders

Faozi, A. N., Priyono, A., \& Yuwono, P. (2013). Ukuran vital tubuh cempe pra sapih dan hubungannya dengan bobot tubuh berdasarkan tipe kelahiran pada kambing Peranakan Etawah. Jurnal Ilmiah Peternakan, 1(1).

France, J., \& Dijkstra, J. (2005). Volatile fatty acid production. Quantitative aspects of ruminant digestion and metabolism, 2, 157-175.

Hartadi, H. S. Reksohadiprodjo dan AD Tillman. (1990). Tabel Komposisi Pakan untuk Indonesia.

Haryanto, B. (1994). Respons produksi karkas domba terhadap strategi pemberian protein by-pass rumen. Jurnal Ilmiah Penelitian Ternak Klepu, 1(2), 49-55.

Kearl, L. C. (1982). Nutrient requirements of ruminants in developing countries. International Feedstuffs Institute.

Kinsella, J. E., Frankel, E., German, B., \& Kanner, J. (1993). Possible mechanisms for the protective role of antioxidants in wine and plant foods: physiological mechanisms by which flavonoids, phenolics, and other phytochemicals in wine and plant foods prevent or ameliorate some common chronic diseases are discussed. Food technology (Chicago), 47(4), 85-89.

Kurniawati, A. (2013). Teknik produksi gas in-vitro untuk evaluasi pakan ternak: volume produksi gas dan kecernaan bahan pakan. Jurnal Ilmiah Aplikasi Isotop dan Radiasi,3(1). http://dx.doi.org/10.17146/jair.2007.3.1.552

Manalu, W., M.Y. Sumaryadi, Sujiatmogo \& Satyaningtijas, A.S. (1999). Mammary gland diferentialgrowt during pregnancy in supporvoleted javanese thin thail ewes. Small Rumin. J Anim Science. 33, 279-284.

Manu, A. E., \& Baliarti, P. P. D. I. E. (2007). Suplementasi pakan lokal urea gula air multinutrien blok untuk meningkatkan kinerja induk bunting dan menyusui serta menekan kematian anak kambing bligon yang digembalakan di sabana Timor (Doctoral dissertation, [Yogyakarta]: Universitas Gadjah Mada).

McDonald, J. W., \& Howard, M. J. (2002). Repairing the damaged spinal cord: a summary of our early success with embryonic stem cell transplantation and remyelination. In Progress in brain research (Vol. 137, pp. 299-309). Elsevier. https://doi.org/10.1016/S0079-6123(02)37023-7

McDonald, P. R., Edward, A., Greenhalgh, J. F. D., Morgan, C. A., Sinclair, L. A., \& Wilkinson, R. G. (2010). Animal nutrition 7th (Ed) Longmans Scientific and Technological.

Moss, A. R., Jouany, J. P., \& Newbold, J. (2000, May). Methane production by ruminants: its contribution to global warming. In Annales de zootechnie (Vol. 49, No. 3, pp. 231-253). EDP Sciences. https://doi.org/10.1051/animres:2000119

Murtidjo, B. A. (1993). Kambing sebagai ternak potong dan perah. Yogyakarta: Kanisius.

Nuriyasa, I. M., Puspani, E., \& Yupardhi, W. S. (2018). Growth and blood profile of lepus nigricollis fed diet fermented coffee skin in different levels. International Journal of Life Sciences,2(1), 21-28. https://doi.org/10.29332/ijls.v2n1.83

Nuriyasa, I. M., Puspani, E., \& Yupardhi, W. S. (2018). Growth and blood profile of lepus nigricollis fed diet fermented coffee skin in different levels. International Journal of Life Sciences,2(1), 21-28. https://doi.org/10.29332/ijls.v2n1.83

Oluremi, O. I. A., Ngi, J., \& Andrew, I. A. (2007). Phytonutrients in citrus fruit peel meal and nutritional implication for livestock production. Livestock Research for Rural Development, 19(7), 1-5.

Ozutsumi, Y., Tajima, K., Takenaka, A., \& Itabashi, H. (2005). The effect of protozoa on the composition of rumen bacteria in cattle using 16S rRNA gene clone libraries. Bioscience, biotechnology, and biochemistry, 69(3), 499-506. https://doi.org/10.1271/bbb.69.499

Perdana, S., Cakra, I. G. L. O., \& Mahardika, I. G. (2020). The effect of concentrate replacement level with gamal leaf (gliricidia sepium) in ransum on rument metabolite products and blood goat profile. International Journal of Life Sciences, 4(1), 66-77. https://doi.org/10.29332/ijls.v4n1.379 
Pamungkas, D. A., YN, K., \& Krisna, N. H. (2008). Produksi asam lemak terbang dan amonia rumen sapi Bali pada imbangan daun lamtoro (L. Leucocephala) dan pakan lengkap yang berbeda. In Seminar nasional teknologi peternakan dan veteriner.

Purbowati, E., \& Baliarti, P. P. D. I. E. (2007). Kajian perlemakan karkas domba lokal dengan pakan komplit dari jerami padi dan konsentrat pada bobot potong yang berbeda (Doctoral dissertation, Universitas Gadjah Mada).

Roseler, D. K., Ferguson, J. D., Sniffen, C. J., \& Herrema, J. (1993). Dietary protein degradability effects on plasma and milk urea nitrogen and milk nonprotein nitrogen in Holstein cows. Journal of Dairy Science, 76(2), 525-534. https://doi.org/10.3168/jds.S0022-0302(93)77372-5

Rusdi. (2006). Dinamika Protein pada Ruminansia.Tadulako University Press, Palu.

Ryle, M., \& Orskov, E. R. (1990). On milk yields and calf rearing. Livestock Research for rural development, 2(3), 58-65.

Sakinah, D. (2005). Kajian suplementasi probiotik bermineral terhadap produksi VFA, NH3, dan kecernaan zat makanan pada domba. Fakultas Peternakan, Bogor (ID): Institut Pertanian Bogor.

Salido, W. L., Achmadi, J., \& Purnomoadi, A. (2016). Komposisi Tubuh Domba Ekor Tipis yang Diberikan Pakan Bungkil Kedelai Terproteksi Tanin dengan Kadar Berbeda (The body composition of thin tail ramsfed with protected tannin-soybean meal in different levels). Jurnal Veteriner, 17(1), 133-142.

Sandi, I. N., Ardana, A. G., Parwata, I. M. Y., \& Teresna, I. W. (2017). Effect of relative humidity on expenditure of body fluids and blood pressure when exercise. International Research Journal of Engineering, IT \& Scientific Research, 3(2), 114-122.

Santoso, B., \& Hariadi, B. T. (2007). Pengaruh suplementasi Acacia mangium Willd pada Pennisetum purpureum terhadap karakteristik fermentasi dan produksi gas metana in vitro. Media Peternakan, 30(2).

Sarwono, B. (1991). Beternak kambing unggul. Niaga Swadaya.

Sio, S., Mahardika, I., Partama, I., \& Suryani, N. (2017). Rumen metabolite of balinese cows that being given stewed water of lannea coromandelica peel as feed additive. International Research Journal of Engineering, IT \& Scientific Research, 3(5), 25-33.

Steel, R. G. D., \& Torrie, J. H. (1995). Prinsip dan prosedur statistika (Terjemahan). Sumantri. PT. Gramedia Pustaka Utama, Jakarta.

Suherman, K., Suparwi \& Widayastuti (2013). Konsentrasi VFA total dan amonia pada onggok yang difermentasi dengan Aspergillus niger secara in vitro. J. Ilmiah Peternakan 1(3): 827-834.

Sung, H. G., Kobayashi, Y., Chang, J., Ha, A., Hwang, I. H., \& Ha, J. K. (2006). Low ruminal pH reduces dietary fiber digestion via reduced microbial attachment. Asian-Australasian Journal of Animal Sciences, 20(2), 200207. https://doi.org/10.5713/ajas.2007.200

Wijaya, G. H., Yamin, M., Nuraini, H., \& Esfandiari, A. (2016). Performans Produksi dan Profil Metabolik Darah Domba Garut dan Jonggol yang Diberi Limbah Tauge dan Omega-3 (Production performance and blood metabolic profiles of garut and jonggol rams that was fed mung bean sprout waste and omega-3). Jurnal Veteriner, 17(2), 246-256.

Yupardhi, W. S., Oka, I. G. L., Mantra, I. B., Suyasa, I. N., \& Suranjaya, I. G. (2014). Gambaran Darah Kambing Gembrong, Kambing Peranakan Etawah, dan Kambing Kacang di Bali (Blood Illustration of Gembrong Goat, Etawah Crossbred Goat And Kacang Goat In Bali). Jurnal Veteriner, 15(4), 494-498. 


\section{Biography of Authors}

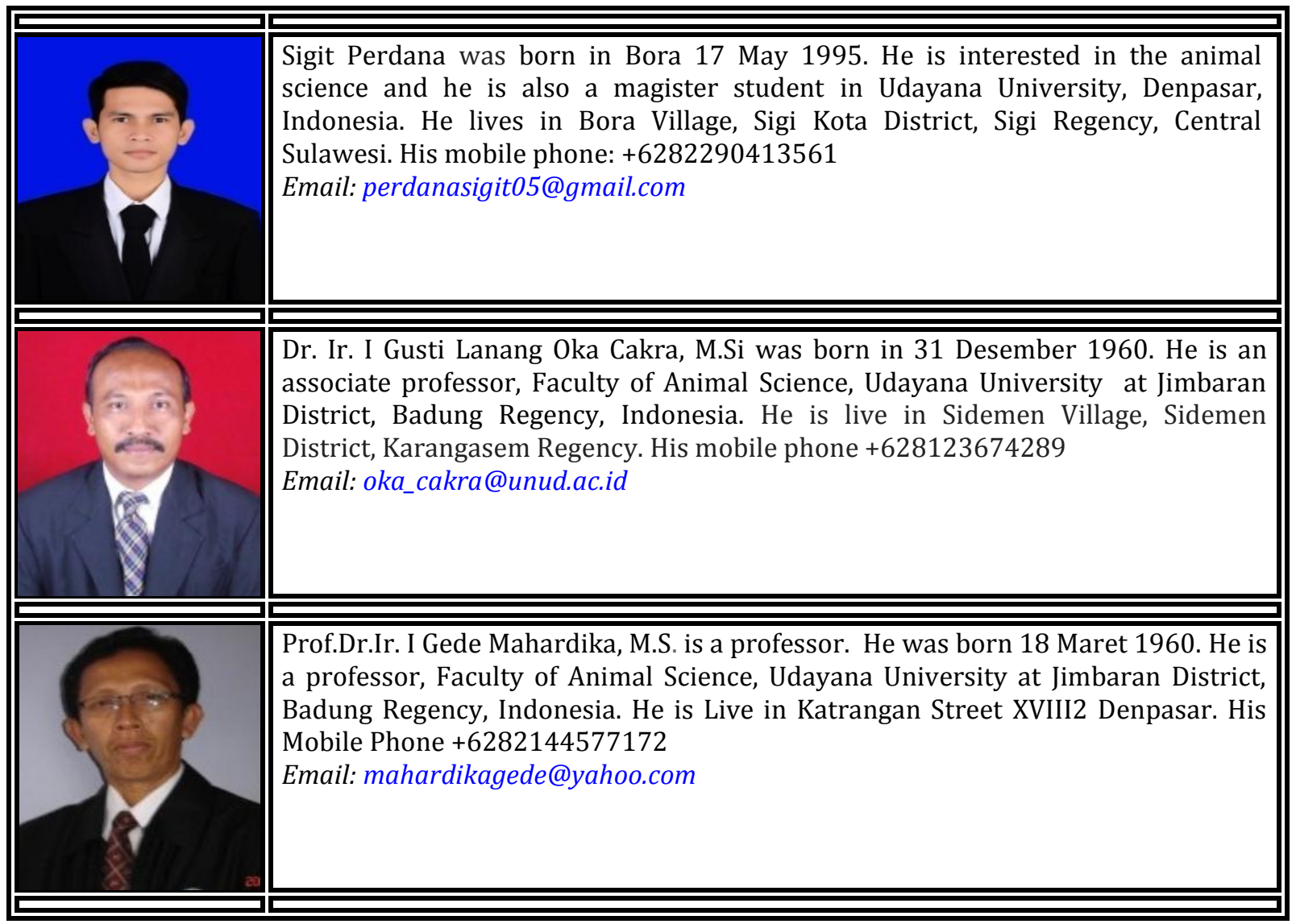

Perdana, S., Cakra, I. G. L. O., \& Mahardika, I. G. (2020). The effect of concentrate replacement level with gamal leaf (gliricidia sepium) in ransum on rument metabolite products and blood goat profile. International Journal of Life Sciences, 4(1), 66-77. https://doi.org/10.29332/ijls.v4n1.379 